Portland State University

PDXScholar

\title{
The European Coal and Steel Community: the Path Towards European Integration
}

Nicholas Hudson

Portland State University

Follow this and additional works at: https://pdxscholar.library.pdx.edu/honorstheses Let us know how access to this document benefits you.

\section{Recommended Citation}

Hudson, Nicholas, "The European Coal and Steel Community: the Path Towards European Integration" (2016). University Honors Theses. Paper 276.

https://doi.org/10.15760/honors.257

This Thesis is brought to you for free and open access. It has been accepted for inclusion in University Honors Theses by an authorized administrator of PDXScholar. Please contact us if we can make this document more accessible: pdxscholar@pdx.edu. 
THE EUROPEAN COAL AND STEEL COMMUNITY:

The Path Towards European Integration

by

Nicholas Hudson

An undergraduate honors thesis submitted in partial fulfillment of the

requirements for the degree of

Bachelor of Arts

in

University Honors

and

Economics/French

Thesis Adviser

John B. Hall, Ph.D.

Portland State University 
Abstract: This inquiry seeks to establish the importance of the European Coal and Steel Community (ECSC) and its key role as the foundation for deeper European integration projects, which ultimately have manifested in the European Union seen today. By the end of the Second World War, the European continent was left in ruins, with nations desperately seeking to rebuild their economies and infrastructures, while also attempting to create a stability that would bring lasting peace to a region historically torn apart by war. European leaders, including the French diplomat Jean Monnet, were faced with the challenge of increasing output and employment opportunities, while preventing neighboring Germany from returning to its maximum strength and inciting further conflict. The ECSC proved the answer to these challenges by demonstrating the economic and political benefits associated with cooperation. Additionally, the Community provided the framework and background for subsequent supranational organizations, which succeeded in drawing more European countries towards the concept of willing integration. Finally, this inquiry examines the theories associated with economic integration and its various stages, both in markets and in policies, while also considering the neofunctionalist perspective that seeks to explain the expansion and deepening of integrated regions through spill-over effects. 
The purpose of this inquiry is to examine the beginnings of European integration and the role of the European Coal and Steel Community (ECSC) within this process. Today, much of the European continent is looked upon as a model for peace and prosperity for the rest of the world. In their paper, "The Economic Impact of European Integration," Andrea Boltho and Barry Eichengreen $(2008,2)$ assert that members of the European Union are effectively integrated, both economically and politically, and that the region is vibrant with transnational activity, with free trade and almost unrestricted movement of capital. However this prosperity is a relatively recent phenomenon, as most of the continent was in ruins by the end of World War Two over 70 years ago. The ECSC served as the first step in the process of creating an integrated and united Europe focused on economic recovery, prosperity, and lasting peace on the continent.

For most of the $20^{\text {th }}$ century, coal and steel could be considered at the center of daily life for Europeans. Used for electricity and massive construction endeavors, these materials proved to be an essential part of most countries' economy. They also proved to be crucial elements towards the expansion of a country's military, with Germany's strong coal and steel industry being credited as helping Adolf Hitler rise to power and create Germany's formidable military force. Following Germany's capitulation in 1945, Western Europe faced two major challenges: fear of a resurgence of German power and thus a return to instability in the region, and the threat of aggression and expansion from the East with the Soviet Union and communism. The ECSC was seen as a solution for both of these threats, as well as a way to expand the economy of all member countries: France, Germany, Belgium, the Netherlands, Luxembourg, and Italy.

Within twenty years, Europe had seen a rapid recovery and expansion of its economy. Of its original stated goals, the ECSC succeeded in accomplishing some, while failing to meet 
expectations for others. However, regardless of its immediate effects on the markets for coal and steel within these six countries, the community, as well as its governing institutions including the High Authority, inspired other countries to follow in further integration, involving more sectors and freedoms to members within the union. The expansion lead to numerous subsequent supranational organizations over the next half century, bringing more countries closer together until the present day with the European Union, which today comprises of 28 closely cooperative member states.

The inquiry also seeks to examine the theory of economic integration, discussing the various levels and forms of integration. In his book, The Uniting of Europe (1958), Ernst B. Haas offers a new take on integration with his understanding of "neo-functionalism." This contribution of theory was developed in the 1950s, and although temporarily declared as obsolete by Haas himself (a claim which he later revoked), the theory has returned to relevance and once again is considered as a useful approach to integration. Haas $(1958,11)$ defines integration as "[c]onceived not as a condition but as a process, the conceptualization relies on the perception of interests and values by the actors participating in the process." In other words, economic interests among several member states will gradually coincide, then proceed to expand and spill over into an increasing number of other fields of activity. The European Coal and Steel Community can be seen as the first step in this process, establishing a common market and setting a precedent for future integration in Europe. 


\section{A EUROPEAN ECONOMY IN THE AFTERMATH OF WORLD WAR II}

\section{a. A Continent in Ruins}

As the Second World War came to a close, Western Europe, particularly France and Germany, was faced with the enormous task of rebuilding their nearly destroyed countries and economies. The postwar European economy had essentially collapsed, with almost every country facing some degree of destroyed infrastructure and loss of human and physical capital. In his book, Who Benefits From Global Violence and War: Uncovering a Destructive System, Marc Pilisuk (2007, 136) paints a grim picture, teaching us that by the end of the war, 70 percent of the industrial infrastructure of Europe was destroyed.

When looked at simply from a standpoint of human loss and the destruction land, towns, and cities, there is little distinction between the victors and the losers in the aftermath of the war. Andreas Staab provides insight into the European postwar climate in his book The European Union Explained (2008). Staab $(2008,6)$ cites the death toll in Europe alone as 15.6 million soldiers and 19.5 million civilians killed. In the Soviet Union, the number is estimated to be between 20 and 24 million military and civilian deaths. Germany and Great Britain, perhaps the worst affected by mass bombing campaigns from both sides, found themselves with 7 million homes damaged or destroyed. By 1945, 50 million were left homeless across the continent.

This resounding loss of life and destruction of infrastructure created deplorable economic conditions which threatened famines and further instability. Rail networks and roads were destroyed, impeding the reconstruction of critically destroyed areas and slowing the revitalization of the economy. Water, heating, and electricity were in need of restoration, as well as houses, 
factories, and entire cities needed to be rebuilt. The six members of the ECSC were no exception to the devastation. Martin Bull and James Newell discuss the situation in Italy in their book Italian Politics: Adjustment Under Duress (2005). Bull and Newell $(2005,20)$ explain that by the end of the war, Italy was faced with low levels of industrialization, territorial and structural dualisms, high levels of both unemployment and underemployment, large wealth inequalities, and a lack of advanced technology and raw materials. In addition, the economy was managed in a relatively protectionist system against the international economic environment, perhaps the most common economic approach in Europe in recent history. Six years after the end of the war in 1951, 43.9 per cent of employees in Italy were employed in the agriculture sector, underlying the country's dire situation. The concern for policy makers in Italy, Western Europe and even the United States was that sustained economic hardships would lead to a resurrection of fascism or a turn to communism that would threaten the peace and stability of the continent once again.

France, perhaps the most instrumental country in the creation of the ECSC, was driven in part by its dire economic situation following the war. In the article "Le plan Monnet et l'économie française en 1950" (1950), author René Streiff describes the impact of the war on the French economy in detail. France's position as a major hotspot between allied and axis hostilities as a result of its German occupation left an enormous economic burden on the country following its liberation in 1944. No sector was spared, with the finance system shattered, communication lines gravely damaged, agriculture stunted by lack of fertilizer, and the industrial and manufacturing sectors decimated by German requisitions during wartime. In all, Streiff $(1950,169)$ indicates the loss of 4.983 billion francs as the cost of German occupation: 2.432 billion as a result of despoliations, 1.832 billion due to general destruction of properties and assets, and the rest coming from charges and costs imposed by the occupying regime and general war operations. The impact 
on the French economy can also be illustrated by the loss of 23.5 billion hours of work lost, which came as the result of Frenchmen of working age unable to contribute to the economy due to imprisonment, deportation, and the Service du Travail Obligatoire (STO), which was the forced labor of 650,000 Frenchman sent to Germany to work for the Nazi war effort. France was thus faced with the task rapidly increasing in the conditions necessary to increase the standard of living of French citizens, while simultaneously assuring the economic independence of the country.

Despite its strict control over French resources and even labor, Germany was faced with equal if not worse conditions by the end of the war. It was in Germany where the pitiable condition of the economy quickly began to cause the most fear among leaders in Western Europe and the United States. In his article, "German Economic Miracle" (2008), author David Henderson provides insight into conditions of the German economy immediately following the country's capitulation. The country was left in shambles, with a significant portion of its working-age men dead, both due mostly to the vicious fighting which took place within the country towards the end of the war, as well as Adolf Hitler's scorched-earth policy. Henderson (2008) teaches us that in 1945, 20 percent of all housing had been destroyed. Like in many other parts of Europe and the world, famine also posed a genuine threat. In 1947, the level of food production per capita was only 51 percent of the level of 1938, one year before the war began. Additionally, 1947 levels of German industrial output was at only one-third its 1938 level. Price control on common commodities imposed by Hitler in the 1930s remained after the war as the occupying allied forces agreed to keep both price control and rationing in place in their respective occupied zones. The system was failing Germans, who were facing severe shortages of goods, including food, and were forced to resort to bartering in one-third of business transactions in the US and British controlled 
zones, as estimated by US military experts in 1947. Germany, like elsewhere in Europe, needed dramatic and substantive aid in order to rebuild and give hope to a peaceful and stable Europe.

\section{b. The Marshall Plan: First Signs of European Integration}

In order for countries such as France and Germany to begin rebuilding their economies, the first priority had to be to prevent the possibility of a renewed conflict. Punishing the losers of war, as done in the Treaty of Versailles following World War I against the Germans and Austrians proved to be a nonviable option after witnessing its results in Germany with hyperinflation and the rise of Nazism. The West was also faced with the new threat of an expanding Soviet threat, with the fear of communism growing and becoming ever more present in occidental politics. A new solution was therefore needed, one of conciliation and reparation, that would serve Europe and make the idea of another continental war not only unfavorable, but unimaginable. Staab $(2008,7)$ suggests this new global environment made it necessary for the United States to be the one to motivate Europeans into action.

The American response to the state of the European continent came in 1948 with the proposed reconstruction plan aptly named the European Recovery Program (ERP), later known as the Marshall Plan. The program sought to provide any willing European nation, including the Soviet Union, with substantial financial aid in order to promote economic reconstruction and growth. Staab $(2008,7)$ notes another key objective, which aimed to block the spread of Soviet communism into Western Europe. Poor economic conditions, combined with postwar election trends indicating an increasing support for left-orientated parties across the continent triggered fear amongst US policy makers. They were alarmed by an environment vulnerable to political instability, and a possible turn to communism. Naturally, the Soviet Union refused the aid, and 
prevented its Eastern European satellite states from receiving it as well. However, 16 other European countries eventually participated in the program, including the United Kingdom, France, and West Germany. Overall, the US contributed more than $\$ 13$ billion in aid, initially in the form of shipments of food, staples, fuel and machinery. Towards the end of the program, which officially halted in 1951, the US had begun offering aid through investments in industrial capacity, inciting further growth and independence of the European economies.

The aid helped to establish liberal market-orientated and capitalist economic systems across Europe. Doing so served to stabilize the continent, as well as create a transatlantic link towards the United States and away from the Soviet Union. Eline Poelmans, in her article "Changes in the Structure of Coal and Steel Industries Under the ECSC (1952-1967): Was West Germany Kept "Small"?" (2012) discusses this new connection across the Atlantic and its implications within Europe. Poelmans $(2012,2)$ explains that the plan, among other objectives, stipulated that Western European nations work together economically and politically in order to receive the economic aid the Americans were offering. The goal was to encourage a degree of European integration, dramatically reducing the likelihood of another war in the region.

The first significant implementation of European integration came in 1948 with the creation of the Organization for European Economic Cooperation (OEEC), eventually renamed as the Organization of Economic Cooperation and Development (OECD) in 1961. This international organization was encouraged and facilitated by the US government to ensure Marshall Plan aid was distributed in an efficient and organized manner. It came as a result of a financial incentive for cooperation that had never before existed within the European continent. Staab $(2008,7)$ further suggests that the OEEC served as the first forum for Western European countries to attempt supranational integration. 
It was through the OEEC that European states first began to witness the effects of economic cooperation through an institutionalized medium. In addition to facilitating the allocation of Marshall Plan aid, the organization also provided the framework for both the creation of further organizations and the implementation of economic programs. One such organization created was the European Payments Union (EPU), which came into existence in 1950 to address new implications of economic cooperation in postwar Europe. Boltho and Eichengreen $(2008,14)$ teach us that the EPU was needed to coordinate a phasing out of exchange controls and other discriminatory trade measures that had been used to regulate the balance of payments during the war and second half of the 1940s. With intra-European trade on the rise, and certain political figures looking towards the creation of a common market, eliminating exchange controls and allowing currencies to be freely bought and sold for trade-related reasons had become necessary.

Without the EPU, European nations confronted issues of disorganization that discouraged governments from liberalizing unilaterally. If one country unilaterally made its currency internationally available for trade, freeing up imports and exports, then consumers would benefit from the cheaper imported goods, while exporters would suffer, unable to sell their products abroad. Since other European countries were not encouraged to similarly relax their own exchange barriers, no country was willing to act first. As Boltho and Eichengreen $(2008,15)$ note, the EPU was thus needed to coordinate this transition, and acted as an institution used to monitor the compliance of governments with their commitments outlined in a Code of Liberalization, which was administered by the OEEC.

Full liberalization of the buying and selling of European currencies for trade was gradually achieved throughout the 1950s. The organizations involved, as well as the aid received through the Marshall Plan can be unquestionably considered a success, as Boltho and Eichengreen (2008, 
15) cite intra-European trade as expanding stoutly from $\$ 10$ billion to $\$ 23$ billion over the decade. European exports grew, as did economic expansion and reconstruction, with economic performance considered strong and growing across the board. However, certain obstacles remained, delaying the creation of widespread and more inclusive integration and requiring international cooperation that had been rare in Europe over the course of its modern history.

\section{c. The German Problem}

Perhaps the first and largest threat to the new and frail peace and stability of the European continent was the fear of a vindictive Germany returning to its prewar power. Initial suggestions of suppressing the West German economy were quickly rejected, however, primarily out of fear it would lead to resentment and new conflict, as it did in the aftermath of the First World War and the rise of Nazism. Poelmans $(2012,6)$ argues the slow recovery of European economies in the immediate aftermath of World War II also provided reason to not punish Germany economically, as much of the continent had been driven by and dependent on the strong performance of the German industry in the prewar period.

With no major external impediments, German recovery would be inevitable. The country, especially in the Western territory occupied by the Allies, had kept its experience and technological knowledge from before the war, which allowed great potential for its industries to return to competitive levels. Germany also had the advantage of controlling the Ruhr region, the industrial heartland of Western Europe, which permitted a large and steady supply of coal, and thus steel. Initially, coal and steel production in this region was supervised and controlled by the occupying allied forces through the International Authority for the Ruhr (IAR). Fear of an increasingly powerful German state dictated this control of production for a number of years following the war. 
The economic and political climate of Western Europe was based by and large around Franco-German relations. The two nations had a long history of almost constant conflict and war, thus stalling early integration between the two former enemies. For half a decade following the end of the war, French policy, largely based off of French diplomat Jean Monnet's Monnet Plan, was focused on keeping West Germany small and under control, while simultaneously expanding and strengthening France's own economy. France agreed to establish the free Federal Republic of Germany in 1949, but only under the condition that West German coal production remained under allied control. In Desmond Dinan's article “Fifty Years of European Integration: A Remarkable Achievement" (2007), Dinan (2007, 1123) explains that doing so allowed France to modernize its own economy by continuing with unfettered access to coal from the Ruhr region, while keeping the threat of German under tight control.

Despite it being positive for French national interest, this policy of control over Germany’s coal and steel was short lived. Due to rising tensions between East and West during the Cold War, the United States began pressing for France to relax its policies on Germany. Dinan $(2007,1122)$ argues a weak West Germany meant a weak Western Europe against the growing Soviet Bloc, whose expanding influence already prevented its satellite states from receiving aid as part of the Marshall Plan. Ignoring France's security concerns, pressure mounted to ease restrictions on Germany, especially in its coal industry, which was instrumental in rebuilding the economy. Poelmans $(2012,7)$ notes that if France could not propose its own solution, it was feared that the Americans would likely increase or even completely eradicate production limits on German steel.

Jean Monnet, who had led the efforts to rebuild the French economy following the war, along with the French Foreign Minister Robert Schuman, were consequently tasked with devising a plan to address all of these issues present in Europe. France needed a solution that would promote 
economic recovery and expansion in both countries, while at the same time keep West Germany small and prevent it from returning to its prewar might.

Karen Alter and David Steinberg, in their article "The Theory and Reality of the European Coal and Steel Community" (2007), discuss the climate in Europe as West German sovereignty become more and more likely. Alter and Steinberg $(2007,3)$ teach us that a scarcity of steel began to concern leaders in Europe, including Monnet and Schuman, who feared that in the face of scarcity in the international market, the advantage would return to Germany, who possessed Europe's most well established steel industry, located in the Ruhr valley. In such a situation, Germany would be able to abuse its dominant position in production and even become capable of rebuilding its military, all while preventing other European nations from renewing their own industries and economy.

With this possible threat in mind, and mounting pressure from the U.S., France came to a conference of Western powers in London in 1950 with the proposal a community of coal and steel industries between five neighboring countries, France, Germany, Belgium, The Netherlands, and Luxembourg, as well as Italy. Dinan $(2007,1123)$ emphasizes that this plan succeeded in satisfying what was once thought of as irreconcilable differences in French and German economic and political interests. He argues that through the creation of a supranational organization, which would manage both countries' production of both coal and steel resources, French and German affairs would be characterized by "cooperation rather than coercion." France would be able to preserve at least a portion of its access to the coal it needed from Germany in order to maintain its steel industry, while Germany regained more control of its own land, industry, and international image.

The new initiative led to the creation of the European Coal and Steel Community (ECSC). It was the first official, entirely European led step of integration based on the recent concept of 
supranationality. The community aimed to create a common market of coal and steel, a step up from any other form of integration attempted in Europe. To understand the Community's goals, as well as the subsequent institutions and organizations created to deepen European integration, it is important to examine the different forms of integration, which have each existed in Europe in the last seven decades and continue to function today.

\section{INTEGRATION THEORY}

\section{a. Customs Union: The Markets of Goods and Services}

Economic integration can be approached by understanding the two dimensions of integration: markets and policies. Willem Molle discusses the distinctions between these two aspects in his book The Economics of European Integration (2006). Molle (2006, 9) summarizes market integration as simply the removal of barriers to movements of products and production factors between integrated member nations. Policy integration is considered the establishment of common policies and institutions within the community. The two dimensions are intrinsically intertwined, with changes in one leading to consequential changes in the other. This spill-over of decisions from one dimension or field of activity to another may often allow for an upward rising spiral of desired effects, a process that continues until the economic benefits have been exhausted. These are characteristics of a neofunctionalist perspective of integration, which was developed by Ernst Haas and examined throughout this inquiry.

The two dimensions of integration, markets and policies, can be broken down further and examined in stages. For Molle $(2006,10)$, market integration can be summarized by three phases. The first is the most basic form of integration, known as a Freetrade Area (FTA). This stage 
removes all trade impediments such as tariffs and import duties, and allows for free internal movement of goods within the integrated region. However, the FTA stops there, leaving each country to maintain and apply its own external customs tariffs and trade restrictions towards third countries. Customs Union (CU) then, is the second stage in market integration. This level of integration retains the characteristics of the FTA in the suppression of all restrictions of trade within the union; however it goes a step further with the equalization of trade tariffs for external countries. The European Economic Community (EEC), established in 1957 with the Treaty of Rome, is an example of a customs unions and was the next step towards deeper integration following the creation of the European Coal and Steel Community.

In addition to equalized external tariffs, the second defining characteristic of a customs union that separates it from the other stages of market integration is free commodity movement. In a non-integrated country, the choice is often made to protect domestic producers from foreign competition. This is done through limitations on the movement of goods between countries, as well as through restrictions on imports, most notably with the use of tariffs. Molle $(2006,65)$ offers a number of motives for creating such obstacles designed to protect domestic interests. Strategic independence is one such reason that was particularly pertinent in Europe during the beginning of the negotiations for deeper integration. As a continent with centuries of near non-stop conflicts and wars, European governments felt their country should not depend on others for strategic goods, especially during times of war and supply shortages. Other economic motives include the defense against dumping, where a national industry may be weakened if it is flooded with cheaper foreign goods, or when wages do not match in the two trading countries and labor is therefore exploited where it is cheaper. Finally, countries feared a lack of diversification originating from the specialization in one or few products would lead to vulnerability in the economy in times of 
economic hardship. Customs unions were argued to serve as a compromise, providing the benefits found in protectionist attitudes as well as the advantages of international trade theory such as comparative advantage.

The key idea behind the theory of customs unions is the gains and losses which are incurred as a result of the establishment of such unions. In his book, The Theory of Economic Integration (1961), Béla Balassa considers the impact of a customs union on trade flow. Balassa $(1961,22)$ distinguishes between what is known as the "trade-creating" and "trade-diverting" effects, which determine that the creation of a customs union is practical if the former outweighs the latter. Trade creation occurs when trade increases between member states and the demand in one country shifts from an expensive protected domestic good to a cheaper product from the partner country. In this case, the countries are benefiting from comparative advantage and the unrestricted movement of goods between nations. Inversely, trade diversion occurs when a country imports a more efficient or cheaper good from a third country, though is forced to impose external tariffs on the good after joining a customs union. In such cases, the demand consequently shifts to imports from a highercost producers from within the union, where imports are free and thus carry a lower net cost.

Unit cost must also be taken into consideration when examining the benefits or losses within a customs union. Balassa $(1961,26)$ teaches us that such benefits or losses depend on differences of unit cost, and that in order to estimate the production effects of a customs union, changes in the volume of trade as well as differences in costs must be combined and considered. In other words, even if trade diversion can be measured to outweigh trade creation in terms of volume of trade, a customs union may still have a beneficial effect on the overall economy of the union. If unit cost differences are considerably greater for goods for which trade has been created compared to goods for which trade is diverted, then a customs union could still be argued to be 
economically advantageous. For Balassa (1961, 27), production effects must therefore be distinguished between positive and negative effects in order to increase the accuracy when analyzing the outcomes of trade in a customs union. Positive production effects are defined as the savings in cost as a result of a shift in purchases from high to low cost supply countries. Negative production costs are then considered to be the extra cost of producing a good in the partner country rather than in a third country, as the supply shifts from low-cost foreign producers to higher-cost partner producers.

To begin to examine the efficiency of customs unions, it is important to consider the impact for the world as a whole. Balassa $(1961,29)$ teaches us that the positive effects from trade creation within a union will amass in member countries only. However, when increasing costs in trading are considered, negative production effects are shared by both member and nonmembers alike. In these circumstances, third countries lose out, though union members are in a position where overall gains are possible even if the negative production effects outweigh the positive ones for the world as a whole. This comes as a result of trade-diverting effects between union countries being partially compensated by the increased division of labor among nonmember countries.

It is difficult to make judgments regarding the possible production effects of a hypothetical customs union without also considering a number of various economic factors. Doing so may help to determine the likely impact of a union on the productive efficiency of the region. For Balassa (1961, 29), such factors include the complementarity or competitiveness of participating economies, differences in production costs, the size of the union, transportation costs, and the level of external tariffs. Molle $(2006,70)$ asserts that according to modern analysis based on mathematical models, regional integration unequivocally benefits member countries and hurts the outside countries. Looking to the EEC and other integration agreements between the six members, 
the effects depended on the category of goods involved. Molle $(2006,85)$ stresses the large positive trade-creation effects on industries for machinery, transport equipment and fuels, and the negative trade-diversion effects on food or agriculture industries, as well as for chemicals and other manufactures.

\section{b. Common Market: Free Movement of Factors of Production}

The third and final stage of market integration is what is known as the common market. The ECSC is the first example of a successful integration experiment in Europe, which established a common market for coal and steel among the six member states. A common market combines the characteristics of the FTA and CU, though goes further to include a fully free internal movement of the factors of production, capital and labor, in addition to the free movement of goods and services. Common external regulation for both goods and production factors are also included common markets. Allowing free movement of production factors carries both positive and negative effects on all countries involved, though overall, the increase in integration can be argued to produce spill-over effects that begin to increase the welfare for each participant.

Each sector of production factors has its own important ramifications in the case for integration. For labor, one of the most notable effects of the creation of a common market is the leveling effects on the price of labor (wages) that comes with the free movement of workers within the community. Molle $(2006,101)$ teaches us that labor market integration can be observed under two conditions: when nationals of one member state may look for and accept a job in another member state with no restrictions, and when self-employed people from one member state are free to settle and work in another member state. Such a level of integration will consequently spill over into other sectors, and result in a further coordination of labor markets, as well as a harmonization 
of employment policies, social policies, and taxes. By doing so, states are more likely to reap the potential positive benefits of integration.

Traditional arguments in opposition to such freedoms are based on a number of factors. Molle $(1961,102)$ cites the pressure on wages that follows an increased supply with an unchanging demand as the first motive for labor movement impediments. Also argued is the increase in unemployment, a rise in government expenditure, primarily on social provisions for foreigners, and the increase in regional disparities. Balassa $(1961,85)$ elaborates more on this final factor, stating that free factor migration may risk being directed primarily to regions with higher factor returns as a result of social and economic overhead or other forms of agglomeration economies. In other words, the movement of labor would proceed from poorer regions to richer ones. In such circumstances, integration may be detrimental and lead to a decline of living standards in the place of emigration if its skilled workers emigrate from the depressed area, consequently diminishing the age structure and increasing the per capita burden of taxes.

Nevertheless, such a level of unrestricted movements may also prove beneficial to member countries involved. Molle (2006, 103) considers three advantages that can be expected from permanent migration between integrated states. First, the supply of labor will have a higher chance to exploit their specific skills and qualities and thus contribute to more trade via increased productivity. Secondly, states or regions demanding labor will benefit and profit from better possibilities of choosing a technology with the ideal capital/labor ratio. Finally, the differences in production are leveled assuming they were due to the compartmentalization of the labor market. Balassa $(1961,84)$ also suggests an increase in trade as a result of immigrants buying various goods from their country of origin, or if new goods are brought back and introduced in the "old" 
country. Balassa insists that under realistic assumptions, the trade-creating effects as a result of a common market will likely prevail over any trade-reducing effects of the free factor movements.

The second aspect of production factors, capital, also gains from a freedom of movement in higher levels of integration. In Europe, the abolition of restrictions on capital flows first appeared in 1957 with the treaty that established the EEC. Initially, it had only been made to the level necessary for the proper functioning of the Common Market which had been created. Balassa $(1961,92)$ explains that the condition of capital movement implies that all enterprises within the integrated region should have access to credit on equal terms, and that both loan and equity capital have the right to move to areas where higher returns are possible. Capital movements within the union are also necessary to ease the shifts in resource allocation that come from the liberalization of trade. The liberalization of capital movement is therefore suggested as a precondition of the optimal functioning of a union.

Capital liberalization, though introduced in the early stages of European integration, proved to be a long and ambiguous process due to the levels of risk and uncertainty associated with it. Perverse movements of capital are potentially both more common and of greater importance compared to any perverse labor movements. According to Balassa $(1961,94)$, the uncertainty associated with the transfer of capital between countries reduces the mobility of said capital, and carries the potential of creating further perverse movements of capital. For these reasons, Molle $(2006,121)$ teaches us that governments may enact a number of impeding measures, such as the use of administrative and legal instruments, currency restrictions, and elevated taxes on foreign profits.

However, there are also strong advantages that come with the integration of capital markets. Molle $(2006,121)$ summarizes these as a diminished risk of disturbances in markets, an 
increase in the supply of capital for better investing, and equal production conditions which contribute to fewer disturbances of competition in the common market. For this reason, integrated unions, including in Europe, work to establish policies in order to take advantage of benefits that come not only with free capital movements, but also with all other freedoms allowed in integrated economies.

\section{c. Economic Policy and its Importance}

Economic policies are essential in integrated communities. They are the glue that holds the countries and the market decisions together. The policies, particularly in Europe, are made through government intervention with the goal of enhancing the economic welfare of members and correcting the imperfections of markets. Molle $(2006,10)$, discusses the economic arguments for policy integration, which are at the core based on welfare increasing efforts. Due to the close cooperation of the members of an integrated community, policies in one country will have direct effects in another. When two states have inconsistent objectives, integrated policy is necessary to prevent the policies of the two countries conflicting and exasperating the others' efforts, as well as to lead to a recovery of the effectiveness in policy making. It also assists companies that operate internationally within the union by removing the extra cost of compliance created by a multitude of dissimilar national regulations. As economic integration advances, unintended consequences, or spill-over effects arise, requiring further economic policies to fully benefit from the newly integrated sectors. This can be illustrated by the removal of tariffs on goods in the EEC, which demonstrated the need to harmonize national tax laws and regulations.

Like integrated markets, economic policy can also be summarized by three different forms. Each comprises of an increasing level of harmonization until reaching an exceptionally high degree 
of coordination and integration. Molle $(2006,11)$ outlines these three forms of economic integration policy: an economic union, a monetary union, and an economic and monetary union. The first, an economic union, is when the common market is balanced with a high degree of coordination on the most important areas of economic policy. These comprise of policies regarding market regulation, competition, and industrial structure; in other words, the areas associated with the common market. It also includes macro-economic and monetary policies, in addition to further policies that relate to social aspects including redistribution policies. The next form is the monetary union, where a single common currency circulates in all member states. In Europe, this process began in 1992 with the signing of the Maastricht Treaty, and became fully implemented ten years later in 2002. Finally, there is the economic and monetary union, which combines the characteristics of both aforementioned unions, with integration typically evolving simultaneously within both policy fields.

Economic integration without policies would fail to progress and would likely result in a return to protectionist or individualistic economies. However, integration of a specific sector or markets as a whole, such as the General Common Market in Europe, often leads to the gradual extension of policies and the level and scope of integration. As Haas $(1958,13)$ teaches us, an integrated section of the economy will lead to the growth of a central decision-making body in order to take on economic pursuits not initially "federated" to the organization. If a market is integrated, like the coal and steel markets of the ECSC, it must be accompanied by new fiscal, labor, welfare, and investment measures created by the central institution, which was the High Authority originally led by Jean Monnet in the case of the ECSC.

It is thus the economic transactions and welfare needs that are the key dynamics that spark the creation of more centralized policies and common institutions found in integrated communities. 
In his article, “Theorising European Integration: Revisiting Neofunctionalism and Testing its Suitability for Explaining the Development of EC Competition Policy," Lee McGowan considers the two inter-related claims of the neofunctionalist integration theory to explain the process of integration. McGowan $(2007,6)$ stresses that initial decisions to integrate often unintentionally creates both economic and political spill-overs that push regional integration forward as a whole. The purpose of this theory was to outline a means for closer integration in a slower and more natural process that would ease concerns of nationalistic European leaders.

Developments in integration as a result of spill-over effects call for the need to harmonize separate policies within a union in order to ensure the success and functioning of integrated sectors. Labor and capital movements within a union demonstrate this process, as well as reveal the notion that policies can come from both good and bad economic conditions. Balassa $(1961,86)$ stresses that factor movements arise from a multitude of factors, including differences in wage policies, government-financed social benefits, and monetary fiscal policies. For example, capital may be induced to move from countries with a less equalitarian tax structure following a change or decision of income redistribution measures. Labor movements may then proceed to move in the opposite direction. Another example, cited by Molle (2006, 104), discusses the free market for labor in Europe, which was realized for most activities by 1970. The freedom for workers to move unintentionally highlighted other obstacles that made the process of deeper integration difficult. Many barriers came from deeply rooted cultural differences and in legal or administrative practices and thus could not be entirely predicted. In response, a central institution attempted to ease the process and bring countries closer together by harmonizing matters such as social security, residence permits, diploma recognition, work conditions, and health and safety conditions. 
Economic integration, particularly when viewed from a neofunctionalist perspective, can thus be seen as a continuous and evolving process. Evidently, the first step of this process was European Coal and Steel Community, conceived by Jean Monnet and his associates, which went on to inspire or directly lead to the development of custom unions, common markets, and ultimately the level of integration that is seen in the European Union today.

\section{THE EUROPEAN COAL AND STEEL COMMUNITY: THE BEGINNING AND EFFECTS ON EUROPE}

\section{a. Early Negotiations}

France's participation in a collaborative community with Germany was a sharp contrast to the customary French foreign policy. Dinan $(2007,1123)$ suggests that cooperation, not coercion would be the new basis for interaction allowing French industries to maintain a level of access to German resources in the Ruhr Valley. The Treaty of Paris, which went on to establish the European Coal and Steel Community, proved to be a turning point, not only for Franco-German affairs, which often dominated and dictated the events of the continent over the last several centuries, but for European affairs as a whole.

In the early discussions of an integrated European project, policy makers were faced by two emerging concepts about the best way to manage an integrated Europe. Staab $(2008,5)$ notes intergovernmentalism on one end, in contrast to the idea of supranationalism on the other. With the latter, national policies and institutions are superseded by internationally managed equivalents, 
such as international courts that have the power to nullify decisions by national courts. On the other side, intergovernmentalists support minimizing the creation of new policies and institutions, instead driving European integration through the cooperation of national governments.

Jean Monnet and Robert Schuman favored a supranational approach to integration. Staab $(2008,8)$ teaches us that an international authority independent of national interests, would greatly decrease the likelihood of another war, or at least on of similar magnitude to the Second World War according to Monnet. He and Schuman worked to create the Schuman Plan, which outlined the framework of the ECSC. In it, a supranational institution named the "High Authority" (HA) would be charged with managing the Community and enforcing its rules and regulations.

Initially, ECSC negotiations began primarily between Europe's two main powers: France and Germany. Konrad Adenaur, chancellor of West Germany, welcomed Monnet's proposal to form a closer ties with France in the form of a community of coal and steel markets. In Poelmans' view $(2012,7)$, despite losing some of Germany's industrial advantages, including the dissolution of the Deutsche Kohlen-Verkaufgesellschaft, a coal cartel in the Ruhr region which controlled nearly the entire German coal industry, Adenaur had much to gain by closely aligning with the French. Proving Germany was willing to work with Western Europe rather than trying to dominate it as it had in recent history, Adenaur hoped to regain democratic legitimacy and expand Germany's international presence. Poelmans $(2012,8)$ emphasizes that doing so would ultimately lead to Germany regaining the rights of a sovereign state and rebuilding its destroyed economy.

Further negotiations went on to include the other four member countries; Belgium, the Netherlands, Luxembourg, and Italy. Negotiations had initially been open to all of Europe, though the events of the Cold War excluded Eastern European countries under Soviet influence. Dinan 
(2007, 1124) goes on to cite further reasons for the negotiation's humble participation, noting countries of Northern Europe who were wary of supranational initiatives, and other nations that were either resolutely neutral or under tight dictatorial regimes, such as Switzerland and Spain. Staab $(2008,8)$ explains Britain's absence, which came as a result of domestic politics. The country had recently elected a left-leaning Labour Party government, which aimed at running an economic program that included a nationalization of industries including the coal and steel sector. Poelmans $(2012,9)$ thus notes that negotiations were left to Belgium, the Netherlands, and Luxembourg (known as the Benelux countries), who were all economically tied to both France and Germany, and shared an important geographical zone known for its industrial outputs. Italy also came to join the negotiations, as they were faced with the same problem as Germany in the face of their defeat in World War II, with the need to reestablish international legitimacy and to combat growing domestic communism.

As time went on, the negotiation process complicated as the Schuman Plan was considered too heavily in favor of France's national interests. Monnet and Schuman initially hoped for continued unperturbed access to German steel factories and coal reserves in the Ruhr Valley, though the Germans eventually negotiated to keep the region under its own control, providing the French simply with limited access to Ruhr resources. Alter and Steinberg $(2007,3)$ also mention the Dutch, who again stunted Monnet and Schuman's ambitions, by rejecting the idea of a highly independent supranational planning body, instead insisting on the creation of a Council of Ministers to keep check on the HA. By the end of negotiations, the result proved to be significantly less ambitious than what Monnet and Schuman had hoped, with diminished supranational powers in favor of characteristics focused more on rebuilding national economies. 
Hudson 26

\section{b. The Treaty of Paris: Founding of the ECSC}

Negotiations closed in on 18 April, 1951 when the "original six" nations signed the Treaty of Paris, officially establishing the ESCS. One year later in 1952, the Community came into full effect, and was to last for a period of 50 years. Alter and Steinberg $(2007,3)$ consider the treaty to have ended as an intergovernmentalist bargain, though despite this assertion, the ECSC can be considered as an important victory for Monnet and Schuman. The treaty served as a blueprint for future political and economic organizations, with the principle of supranationalism secured as a legitimate form of political organization for future communities and unions.

Although characteristics of intergovernmentalism were present in the Treaty of Paris, supranational institutions with real influence did emerge as Monnet had hoped. The HA was the principal institution, and as Alter and Steinberg $(2007,3)$ teach us, was given authority to create decisions, fine firms, and withhold funds to encourage compliance of the rules established within the ESCS. Miroslav Jovanović expands on this in his book European Economic Integration: Limits and Prospects $(2002,6)$, writing that the HA was tasked with facilitating investment programs, establishing production quotas in the event of crises, and influencing prices. Another supranational institution came in the form of the European Court of Justice (ECJ), which adjudicated disputes among anyone involved in the Community, including member states, European institutions, and private sectors affected by the treaty, such as firms and unions.

As the Dutch and other smaller member states of the Community had insisted, the Council of Ministers was included in the treaty, which was established to safeguard the national interests of all involved. Jovanović $(2002$, 6) notes the objection by Belgium, Luxembourg, and the Netherlands, who feared the possibility of the HA escaping democratic control and giving unfair 
advantage and power to certain states. The Council of Ministers was thus created to serve as a link between the national governments of each member state and the HA itself. Additionally, the Treaty also saw the establishment of a "common assembly," made up of national parliamentarians and given supervisor power, and associations for each industry, employers, and unions. The end result was an international community managed by a supranational authority but held accountable by intergovernmentalist institutions.

The Treaty also clearly outlined the objectives of the ECSC, which were stated in the Preamble. Jovanović $(2002,6)$ summarizes these goals, suggesting that perhaps most important was the maintenance of peace, as it was mentioned three times in the Preamble alone. Additionally, the Treaty called for a substitution of old rivalries, an avoidance of bloody conflicts, and a substantial increase in the standard of living in each member nation. The principles of the ECSC were also including, citing an orderly supply in the common market for coal and steel, equal access to the sources of production for consumers in the Community, the ban of price discrimination, and the call for a systematic expansion and modernization of production.

In addition to the institutions and principles, the Treaty also established a framework of rules that would bolster the competitive nature of the market. Alter and Steinberg $(2007,4)$ outline elements of the framework, which included the obligation for transparency with respect to prices, measures to avoid illegal subsidization of industry, a ban of cartels, transparency of labor practices, and an equalization of transport rates for all steel firms regardless of nationality. The Treaty also considered foreign policy, giving the High Authority, under the supervision of the Council of Ministers, permission to negotiate and establish diplomatic relations with foreign governments in matters relating to coal and steel. 
While the agreement signed in Paris did fall short of Jean Monnet and Robert Schuman's initial aspirations, the end product did succeed in establishing institutions capable of coordinating the six member state's coal and steel industries. The Treaty served as the first step towards a united and integrated Europe, with optimistic predictions from Jean Monnet about the Community's future. Philippe Mioche cites such optimism in his book Les Cinquante Années de l'Europe du Charbon et de l'Acier (2004). Mioche $(2004,15)$ quotes the head of a French iron foundry following a meeting with Jean Monnet in October of 1952, claiming "M. Monnet, très optimiste, considère qu'il faut encore deux ans pour réaliser une armée, une autorité politique et une monnaie commune à l'Europe, et dans cet ordre."1

\section{c. Early Years and Effects of the ECSC}

Expectations were high in the early years of the ECSC. Owing to the need to rebuild economies after WWII, global demand for coal and steel was strikingly high, and predicted to remain so for a significant period by the founders of the ESCS. Coal was still the most common source of energy for most of the developed world, and steel was becoming increasingly popular as the primary material used in construction and the production consumer goods, such as motor vehicles, which were seeing a quickly rising demand. For Mioche $(2004,8)$, creating an international community of former enemies based on coal and steel was also symbolic, as until recent times the materials had represented the strength nation, as they were seen as the foundation of a nation's military might.

For the six member countries, barring Italy, the coal and steel industries were already an important part of their economies. Belgium, Luxembourg, and parts of France, Germany, and the

\footnotetext{
1 "Mr. Monnet, very optimistically, considers that only two more years are necessary to witness an army, political authority, and common currency realized in Europe, and in this order."
} 
Netherlands all formed a region considered the industrial backbone of Western Europe. The vast majority of Western European coal, iron ore, and steel production came from this small region named the "industrial triangle" for its shape of an inverted triangle. According to Mioche (2004, 9), together, the six nations accounted for $16 \%$ of the world's production in coal, and $20 \%$ for the production of steel. In 1952, as Poelmans $(2012,9)$ teaches us, each country already produced steel, and all but Luxembourg produced coal. Steel plants were often located in such a way to find a balance between supply costs of the raw materials and the freight or transportation costs of the finished products.

Alter and Steinberg $(2007,5)$ examine Italy, who geographically isolated and distant from the industrial triangle, and among the least internationally competitive steel producers in Europe. On account of negotiations in the Treaty of Paris, Italy and Belgium were each granted exceptions for certain ECSC requirements allowing them to maintain protection for the first five years of the Treaty. During this time, Italy was able to grow its steel industry through a combination of strong public sector investments, tariffs, subsidization of scrap inputs, and increased concentration of ownership with the aim of creating economies of scale. The measures worked, with Italy's steel production levels increasing from 3 million tons in 1951 to 9 million tons in 1961, and 12.7 tons in 1965.

However, despite its early successes and bright predicted future, by 1958 the ECSC had run into problems. Until 1957, the Community's coal production had boomed, causing little doubts among politicians. Western Europe was faced with a "coal crisis", brought on by a number of factors, hurting the industry in all member countries. Poelmans $(2012,10)$ cites these factors as increasing production costs, the availability of cheaper foreign coal from countries like the U.S., Poland, the USSR, South Africa, and Australia, and the increasing demand for cheaper and more 
efficient energy sources, most notably oil. These elements, coupled with a significant global overproduction of coal, meant the coal industries of the Original Six were quickly becoming old and obsolete in the face of a competitive and changing global market. According to Gilbert Mathieu in his article "Dans l'histoire de la CECA, du rose et du gris," published in the French newspaper Le Monde (1970, 2), within 17 years, the quantity of coal mined by the Six had decreased by 28 percent since the Community's implementation in 1952.

Conversely, and fortunately for the Community and Jean Monnet's hope to demonstrate the potential of integrated organizations, demand for steel continued to grow over the next two decades. High demand for durable goods in an increasingly consumerist society as well as the global rebuilding of cities and economies as a result of WWII both propelled steel to significant international economic importance. Poelmans $(2012,11)$ further suggests that when war came to Korea, world demand only increased along with prices with them. According to Mathieu (1970, 3), production of steel consequently rose pointedly, increasing from 42 million tons to 107.3 million tons between 1952 and 1969. International collaboration between countries and firms saw production levels surpass those from before WWII in each country, as well as smaller economies of the ECSC like Belgium and Italy benefitting due to the increased opportunity to establish large and integrated firms through joint investments.

The accomplishments of the ECSC did not stop at its member countries, however, as foreign trade and exports to Europe and around the world saw unprecedented success in the decades following its creation. Boltho and Eichengreen $(2008,2)$ teach us that immediately following WWII, foreign trade was at an extreme low, with the volume of exports from Western Europe barely above levels from over 40 years prior in 1913. Gradually, member countries shifted from self-reliance, then to exchange of raw materials within the Community, to eventually 
importing and exporting materials around the world. As Poelmans $(2012,11)$ elaborates, in 1952, 91 percent of the Community's coal and iron ore used for steel production came from within the industrial triangle, though by 1967 this figure had decreased to 73 percent. This drop coincided with a shift in economic orientation, with many steel firms opting to relocate in more market orientated locations, in close proximity to local markets rather than in the vicinity of fuel (coal) and material supplies.

Firms began to look globally, and as a result of cheaper energy costs and cheap overseas supplies, new established steel firms began increasingly relocating within the vicinity of tidewater, ideally in areas with direct access to the sea. With cheaper supplies becoming available from foreign suppliers, and more efficient and cheaper ways to ship finished steel products abroad, trade increased, and with it the output of integrated industries and firms. Mathieu $(1970,3)$ notes that during this period, steel deliveries between the Six rose tenfold from 1.8 million tons to 17.6 million tons, despite steel production only rising by a factor of 2.5 , from 4.3 percent to 16.5 percent. These figures suggest an increase of trade both within the Community, as well as with non-member states in Europe and other parts of the world, contributing to massive economic expansion as seen by the Wirtschaftswunder in Germany and Les Trente Glorieuses in France.

\section{BEYOND COAL AND STEEL: FURTHER INTEGRATION}

\section{a. Investigating Further Integration}

In its first two decades, the ECSC saw both success and failure, accomplishing certain goals set at its creation, as well as leading to other unforeseen achievements. At its foundation, the Community was formed with two main goals in mind: to promote economic growth and expansion through 
collaboration, and to keep West Germany small, preventing it from growing to its former strength and inciting more conflict within the war-torn continent. The latter, it can be argued, was a failure. West Germany, with its reawakened political and economic independence, played a key role in the Community's economic success, with a number of German firms dominating Western Europe's coal and steel markets. However, the outcome of this supposed failure proved beneficial to both the ECSC and to Europe as a whole.

France, despite its initial efforts, was unable to keep West Germany small. German experience, advanced technology, and control of the resource rich Ruhr region were among the factors that led to Germany's dramatic economic recovery and expansion. Staab $(2007,11)$ cites West German GDP rising by 40. Percent between 1955 and 1964. In contrast to its earlier economic success under Hitler, Germany was now deeply embedded in a European structure that was mutually beneficial for all countries involved. Poelmans $(2012,24)$ suggests that much as it is today, Germany became the driving force behind Europe's economic revival. The country's economic strength, which relied on the economic and political cooperation with other ECSC countries to maintain it, succeeded in making the idea of war between France and Germany, Europe's largest and oldest enemies, unthinkable.

The strong economic recovery was not limited only to German, as each of the six member countries saw dramatic economic recoveries in their coal and steel industries and beyond. The countries of the ECSC demonstrated the efficacy of collaboration and set the precedent for further integration for the rest of the continent. Jean Monnet, after resigning his post as president of the High Authority following the failure of a European Defense Community, was not discouraged with his aims of establishing a federal Europe. Staab $(2007,10)$ explains that Monnet, along with Belgian Prime Minister Paul Henri Spaak, each shared a common interest and motivation for 
pursing deeper integration. With the support of each of the six ECSC member countries, a committee was established, led by Spaak, with the sole purpose of investigating future European integration projects.

The committee, spurred on by the economic success of integration, also came as a result of the earlier mentioned spill-over effects explained by neofunctionalists. As Dinan (2007, 1124) suggests, the ECSC encouraged and required the close cooperation of governments, manufacturers, and interests groups across borders with each other and the supranational institutions of the ECSC, most notably the High Authority. These increased interactions created pressure for national governments to transfer responsibility for related policy areas to other and newly created institutions, and to expand the range of European governance and its capabilities and sectors where it has influence.

The first expansive step came in the form of the European Atomic Energy Community (EURATOM), which sought to integrate Europe's atomic industry. Staab $(2007,10)$ teaches us that in addition to the original six nations of the ECSC, Spaak and other members of the committee hoped Britain would this time agree to participate in an integration project. The UK, however, sought only limited integration in the form of a free trade area, quelling immediate hopes for a British inclusion in the new European project.

The European Economic Community (EEC) was the next proposed project, further vindicating neofunctionalist theorists. The aim of the new community was to establish a common market for all industrial goods, not just limited to coal and steel, to maintain peace in the region and continue to build towards a closer union of European nations. Although the EEC established a customs union with a common external tariff, Dinan $(2007,1125)$ further notes that the EEC also 
aspired to facilitate the free movement of these goods, as well as capital, services, and eventually people.

In 1957, the EEC and EURATOM were officially established with the signing of the Treaties of Rome. Dinan $(2007,1126)$ argues that the Treaty was a hard-fought political compromise due to fundamental differences within the domestic scene of the countries involved. Germans supported the idea of further tariff reductions to increase trade and open markets within Europe, while strong protectionist sentiments persisted in France despite Monnet and other prominent politician's influence. In the Netherlands, which had a small and open economy, most voices supported full liberalization of trade at a rate faster than what Germans or other open economies preferred. During negotiations, West German Chancellor Konrad Ardenauer succeed in convincing skeptics within Germany by highlighting the importance of positive relations with France and embedding the new Federal Republic within European institutions. In France, EEC advocates prevailed when they succeeded in negotiating additions into the Treaty of Rome that would include common agriculture policy and trade arrangements, each providing substantial benefits for France and its colonies.

Negotiations and final results of the Treaty of Rome highlight the importance and the influence of the ECSC in pushing forward the idea of European integration. The goals of the two treaties that established the Communities were similar in nature, as Staab $(2007,11)$ cites the Treaty of Rome creating the EEC to promote a "harmonious development of economic activities, a continuous and balanced expansion, and increase in stability, an accelerated raising of the standard of living and closer relations between the states belonging to it." The treaty also relied heavily on the design of the ECSC in terms of its institutions, as Dinan $(2007,1126)$ notes the establishment of an executive Commission, a parliamentary assembly with limited powers, a 
Hudson 35

Council designated to represent national interests during decision making processes, and a Court of Justice. The enclosures of the Treaty of Rome not only underlined the importance and lasting influence of the ECSC, but it also represented a step forward in integration, as the new communities evolved from representing simply a dramatic step forward in Franco-German relations, to a revolution in the economic and political relations between a number of European nations.

\section{b. Next Steps and Enlargement}

By the end of negotiations, both EURATOM and the EEC consisted of the same six members of the ECSC. However, in 1961 the UK finally conceded to the idea of deeper integration and submitted its first application for the EEC. However, it was now France's president, Charles de Gaulle, who was hesitant towards the inclusion of Britain in the European project. He blocked the first application, and again in 1967 when the UK submitted a second request to join the EEC. Staab $(2007,11)$ cites the reasons for the former French resistance leader's rejections as stemming from his fear of the UK not having a true "European vocation," believing that Britain would act simply as a champion of US government policy if accepted into the Community.

Britain, safe from the veto of de Gaulle who had resigned as president of France in 1969, finally succeeded in joining the EEC in 1973. Shortly thereafter, Ireland and Denmark, both economically tied to the United Kingdom, also succeeded in joining the Community. As Dinan (2007, 1128) teaches us, over the following decades, more countries followed suite, with Greece, Portugal, and Spain all applying for membership in the hope of strengthening their new found democracies, rebuilding their international image, and receiving much needed economic assistance. Countries were motivated to join by the positive impacts of the new integration project, 
which Jovanović highlights in his paper "European Coal and Steel" $(2005,13)$ as the an increase in production and employment of resources, rise of specialization and economies of scale, increased research and development, and improvement in the management of both production and distribution processes. With growing membership, EEC devised a new goal to transition to a single market: an entirely new level of European integration.

Obstacles arose, however, as during the 1970's Europe was faced with an international oil crisis and an abrupt end to strong post-war economic growth. Dinan $(2007,1130)$ further notes that Europe was also faced with the growing challenge of competing with the often cheaper and more reliable products from the United States and emerging Asian economies such as Japan and South Korea. Europeans thus had more incentive than ever to maximize economies of scale and learn to compete globally, tasks facilitated best by deeper integration within the continent. As crises past, and European nations became accustomed to the new global economic environment, plans resumed for a single European market. The concept finally came to fruition with the Single European Act (SEA), which committed member countries to the goal of creating a single European market by the end of 1992 .

The SEA and its Single Market Program was accepted throughout the members of the EEC. Its main ambition called for the increase in spending on economic and social cohesion, aiming to bring poorer countries closer to the Community's economic norm. For Jovanovic $(2005,22)$, the SEA succeeded in making European goods more competitive on the global market in part through the removal of Non-Tariff Barriers (NTBs) and the promotion of cooperation of firms across national borders. The success of the Single Market Program proved to be the biggest advancement towards the integration process of Europe since the Treaty of Rome in 1957. However, the program 
in itself was not an end goal, but rather a step towards another objective of an economic and political union.

In 1992, this next objective was manifested in the Maastricht Treaty, which formally merged the EEC into the European Union (EU). The next stop was thus the ambitious mission of creating a monetary union, where members had not only a common market, but also a common currency and single central bank. Despite hesitations from countries like the UK, and uncertainty of the benefits of a common currency, the plan eventually came to fruition with the Euro entering circulation in 2002. Today, the EU successfully ensures the free movement of people, goods, services, and capital at unprecedented levels, with the Euro serving over 175 million people as the official currency of 19 countries. Boltho and Eichengreen $(2008,2)$ underline the success of the European integration project by noting the multiplication of the volume of Western European exports by nearly 50 times the level in the aftermath of WWII. Intra-European trade also has reached unprecedented highs, and capital movements within the Union almost completely free. European integration has thus blossomed from its uncertain beginnings in 1952 with the ECSC to the near full integration of over 505 million people across 28 member states of the EU today.

\section{CONCLUSION}

This inquiry has sought to establish the importance of the European Coal and Steel Community and its implications on the establishment of economic and political cooperation in Europe today, which has culminated in the European Union and near full economic and political integration among its member states. Amidst a continent in ruins following the end of WWII, the ECSC served 
as the foundation and first steps towards a peaceful and prosperous community of several nations brought together in one supranational union. The supranational European project, dreamed up by Jean Monnet, evolved from a monumental shift in foreign relations between primarily France and Germany, to a revolution in the economic and political relations within almost an entire continent.

The inquiry has also sought to outline the theory of economic integration and establish the importance of spill-over effects in accelerating the integration process. In Europe, spill-over effects began to appear and be noted during the early years of the European Coal and Steel Community. The Community, as well as the Treaty of Paris which formally established it, provided essential framework and influence for further integration projects in Europe. Each stage of economic integration has been applied in Europe, with many of its original institutions still in place and benefiting millions today.

Over the last 70 years, the European theater has been witness to significant economic and political change. In the immediate aftermath of WWII, the continent was faced with the task of rebuilding its ruined economies, while also containing West Germany in an attempt to keep the nation small and prevent any return to its prewar power. France spearheaded these efforts, under the guidance of Jean Monnet, leading the creation of the European Coal and Steel Community, with goals of promoting economic growth and peace among all member nations, and preventing another rise of a dominant and aggressive Germany. The Community established a common market for coal and steel, two indispensable resources in the global economy, and promoted trade and cooperation between countries, allowing economies and trade to grow at a rate not yet seen in Europe. The new concept of deep economic cooperation succeeded in reviving destroyed economies, and making the thought of another major European war almost unthinkable. 
Overtime, institutions evolved and developed, policies spilled over from one economic sector to another, and more and more countries saw the benefit of cooperation and integration. The ECSC and its institutions including the High Authority led to the creation of more supranational organizations, gradually increasing their reach and powers as national governments were motivated in include more sectors of their economies in integrated unions. While the Treaty of Paris officially expired in 2002, traces of the ECSC are still present today, with the core and executive branch of the ECSC, the High Authority, still present today under the form of the European Commission, which serves as the executive body of the EU. With free trade, free movement of most economic factors, economic prosperity, and peace at all-time highs, integration in Europe can be considered to be an enormous success in these regards. The European project can trace its beginnings to the determined work of French diplomat Jean Monnet and his contributions to the European Coal and Steel Community, which set the wheel in motion for European integration and provided apt justification for his name as the "Father of Europe." 


\section{Bibliography}

Alter, Karen, and David Steinberg. "The Theory and Reality of the European Coal and Steel Community." Buffet Center for International and Comparative Studies Working Papers (2007). Print.

Balassa, Bela A. The Theory of Economic Integration. Homewood, IL: R.D. Irwin, 1961. Print.

Boltho, Andrea, and Barry Eichengreen. "The Economic Impact of European Integration." Discussion Paper Series Discussion Paper No. 6820 (2008). Print.

Bull, Martin J., and James Newell. Italian Politics: Adjustment under Duress. Cambridge, UK: Polity, 2005. Print.

Dinan, Desmond. "Fifty Years of European Integration: A Remarkable Achievement." Fordhamn International Law Journal 31.5 (2007). Print.

Haas, Ernst B. The Uniting of Europe: Political, Social, and Economic Forces, 1950-1957. Stanford, CA: Stanford UP, 1958. Print.

Henderson, David R. "German Economic Miracle." The Concise Encyclopedia of Economics. 2008. Library of Economics and Liberty. Web.

Jovanović, Miroslav. "European Coal and Steel." The Economics of European Integration Limits and Prospects. Cheltenham, UK: Edward Elgar, 2005. Print.

Jovanović, Miroslav. European Economic Integration: Limits and Prospects. London: Routledge, 2002. Print.

Lee McGowan. "Theorising European Integration: Revisiting Neofunctionalism and Testing Its Suitability for Explaining the Development of EC Competition Policy." European Integration Online Papers (2007). Web. 
Mathieu, Gilbert. "Dans L'histoire De La CECA, Du Rose Et Du Gris." Le Monde 9 May 1970, No. 7,874 ed. Print.

Mioche, Philippe. Les Cinquantes Années De L'Europe Du Charbon Et De L'Acier. Commission Européenne, 2004. Print.

Molle, Willem. The Economics of Integration: Theory, Practice, Policy. Fifth Edition ed. Aldershot: Ashgate Limited, 2006. Print.

Pilisuk, Marc. Who Benefits from Global Violence and War: Uncovering a Destructive System. 2007. Print.

Poelmans, Eline. "Changes in the Structure of Coal and Steel Industries under the ECSC (1952-1967): Was West Germany Kept "Small"?.” Essays in Economic \& Business History, 2012. Print

Staab, Andreas. The European Union Explained: Institutions, Actors, Global Impact. Bloomington: Indiana UP, 2008. Print.

Streiff, René. “Le plan Monnet et l'économie française en 1950. ” L'information Géographique, Volume 14, n5, 1950. pp. 169-182. 